\title{
突発性難聴に対するバトロキソビン製剤の効果
}

\author{
弘重 光一・山田洋一郎・田中 正美 \\ 山内 由紀・大塚 健司・池田稔
}

\section{The Efficacy of Batroxobin Preparation for Treatment of Sudden Deafness}

\author{
Kouichi Hiroshige, Yoichiro Yamada, Masami Tanaka, \\ Yuki Yamauchi, Kenji Otsuka and Minoru Ikeda \\ (Nihon University School of Medicine)
}

\begin{abstract}
Substantiated treatment methods for sudden deafness have not been established. We administered a batroxobin preparation (Defibrase ${ }^{\circledR}$ ) with a steroid to 17 patients with sudden deafness, most of whom were resistant to a steroid therapy regimen in previous treatment, and observed symptom improvements in 17 respective ears. Results showed $76.5 \%$ mild or better improvement. Because the majority of the subjects were steroid resistant, this rate can be considered relatively high. No side effects were detected, but plasma fibrinogen levels decreased to $50 \mathrm{mg} / \mathrm{dl}$ or below in 8 patients during the treatment regimen. This point remains to be investigated to confirm the drug's safety. Steroid and batroxobin are assumed to act via different modes of action. It is worthwhile to try batroxobin for patients with sudden deafness whose symptoms and disease are intractable when administering steroids.
\end{abstract}

Key word : sudden deafness, batroxobin, fibrinogen

\section{はじめに}

突発性難聴の原因にはウィルス感染，循環障害をはじ め多くの説があるが，いまだ決定的な単一の見解はない， 治療法としてはステロイド剤と高圧酸素療法が有効な方 法とされるが，日常診療に执いては，これに加えていく つかの治療法が併用されているのが現状である.

バトロキソビン製剤(デフィブラーゼ®)は血漿フィブ リノゲン濃度を減少させ末梢循環改善をもたらすとされ， 突発性難聴に対寸るその有用性がいくつか報告されてい る1) 4). 今回われわれはステロイド剤に本剤を併用し， その効果を検討したので報告する.

対象および方法

対象は1992年 1 月より1994年 8 月までに当科を受診し
た突発性難聴患者のらち，ステロイド剤による治療効果 が不十分と思われデフィブラーゼ®を使用した 17 症例 17 耳である．それらは男性 7 例，女性10例で年齢は17歳か ら 68 歳, 平均 51.5 歳, 発症より受診までの日数は発病当 日から第 21 病日，平均第5.5病日であった。突発性難聴 の診断招よび聴力改善の判定は厚生省特定疾患突発性難 聴調査研究班の基準に基づいておこなった（表 1，2）.

他院にてステロイド剤を投与されていた 1 例を除き初 診時よりステロイド療法を招こなった。 ステロイド投与 汇関しては難聴の程度により初回量を決定し，以後 1 2 週間の漸減投与を原則とした。初回量は外来加療の場 合，経ロにてプレドニゾロン一日量 $40 \sim 60 \mathrm{mg}$ より開 始(10例), 入院加療の場合点滴にてメチルプレドニゾロ ン 125 500 mg またはデキサメタゾン $8 \mathrm{mg}$ から開始 
表 1 突発性難聴の診断基準 (昭和48年厚生省班研究報告書)

I . 主症状

1 ）突然の難聴

文字通り即時的な難聴，または朝，目が覚めて気付く よらな難聴.ただし, 難聴が発生したとき“就寝中” とか“作業中”とか，自分がそのとき何をしていたか が明言できるもの.

2 ) 高度な感音難聴

必ずしも“高度”である必要はないが，実際問題とし ては “高度”でないと突然難聴になったことに気付か ないことが多い。

3 ) 原因が不明, または不確実 つまり，原因が明白でないこと。

II. 副症状

1) 耳鳴

難聴の発生と前後して耳鳴を生じることがある.

2 ）めまい，および吐き気，嘔吐

難聴の発生と前後してめまいや, 吐き気, 嘔吐を伴う ことがあるが，めまい発作を繰り返すことはない，

〔診断の基準〕全条件を満たするのを確実例

確実例 I. 主症状, II. 副症状の全事項をみたするの.

疑い例 I. 主症状の 1）2）の事項をみたするの [参考]

1) Recruitment 現象の有無は一定せず.

2 ) 聴力の改善・悪化の繰り返しはない.

3 ）一側性の場合が多いが，両側性に同時䍜患する例もあ る

4 ) 第UII脳神経以外に顕著な神経症状を伴うことはない.

表 2 聴力改善の判定基準(昭和59年改)

1. 治癒

1) $250,500,1000,2000,4000 \mathrm{~Hz}$ の聴力レベルが $20 \mathrm{~dB}$ 以内にもどったもの

2 ) 健側聴力が安定と考えられれば，患側がそれと同程度 まで改善したとき

2 . 著明回復

上記 5 周波数の算術平均值が $30 \mathrm{~dB}$ 以上改善したとき

3 . 回復 (軽度回復)

上記 5 周波数の算術平均值が $10 \sim 30 \mathrm{~dB}$ 改善したとき

4. 不変 (悪化を含む)

上記 5 周波数の算術平均值が $10 \mathrm{~dB}$ 末満の変化

（6 例）とした。発症よりデフィブラーゼ®投与までの日 数は，第 3 病日から第 22 病日で平均 12.2 病日であった。 デフィブラーゼ®の使用にあたっては，全症例を入院加 療とした.デフィブラーゼ®の投与方法は，初回量を10 (12例) または20( 4 例) バトロキソビン単位(以下 BU) と
し(但し 1 例のみ $5 \mathrm{BU}), 2$ 回目以降は血漿フィブリノ ゲン濃度が $100 \mathrm{mg} / \mathrm{dl}$ 以上であることを確認後， 10 BU 投与とした.

初診時, 血液検査として血算, 生化学検査に加え, 出 血・凝固機能検査としてはフィブリノゲン濃度, プロト ロンビン時間(以下 PT)，部分トロンボプラスチン時間 (以下 APTT), 出血時間を施行した. デフィブラーゼ® の投与開始後は頻回にフィブリノゲン濃度, $\mathrm{PT}$, APTTを測定した.

\section{結果}

1. 聴力の変動

初診時, デフィブラーゼ®投与前，デフィブラーゼ® 投与 1 週後， 2 週後および 1 力月後の純音聴力の変動を 検討した。平均聴力としては $250 \mathrm{~Hz}$ から $4000 \mathrm{~Hz}$ まで の 5 周波数の算術平均値を用いた. 全症例の平均値は, 初診時よりそれぞれ $85.2 \mathrm{~dB}, 88.7 \mathrm{~dB}, 77.0 \mathrm{~dB}, 70.5 \mathrm{~d}$ B， 66. $1 \mathrm{~dB}$ であった(図 1 ). 各症例の経時的聴力変動 を(図 2 )に示す.

2 . 聴力の改善度

聴力改善の評価は, 治癒 1 例 $(6 \%)$, 著明回復 5 例 (29\%)，軽度回復 7 例 $(41 \%)$ ，不変 4 例(24\%)であり， 軽度回復以上は13例， $76.5 \%$ であった。

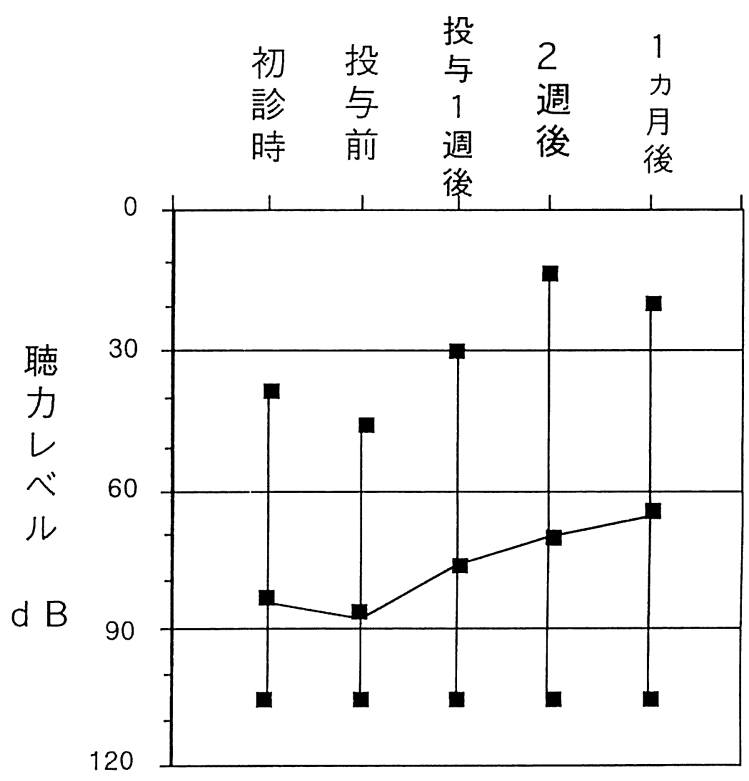

図 1 聴力の範囲とその平均値 


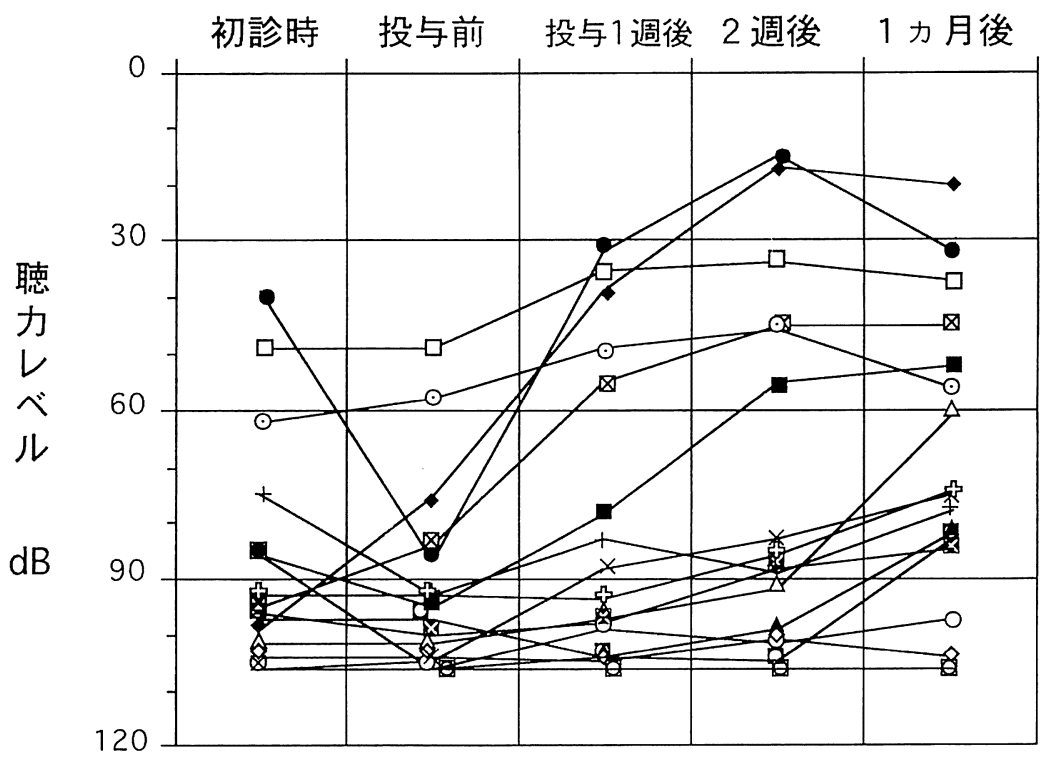

図 2 各症例の聴力変動

\section{3. 副作用}

17症例中 8 例に拈いて, 血漿フィブリノゲン濃度が 50 $\mathrm{mg} / \mathrm{dl}$ 以下に低下し，またそのらち PT, APTT 值が有 意に延長した症例を 2 例認めたが，出血の持続等の臨床 上問題となる所見は認められなかった。

4. デフィブラーゼ®の著効を示した症例

デフィブラーゼ®併用により著明な聴力改善を示した 代表的症例を 1 例呈示する.

症例 : 51歳, 女性.

現病歴：1992年 4 月 21 日午前11頃突然右難聴および耳 鳴が出現. 夕方近医耳鼻咽喉科を受診.4月22日起床時 より回転性眩量が出現し当科紹介受診となり即日入院と なる・

既往歷 : 特記すべきことなし.

経過 : 初診時の平均聴力は右側 $39 \mathrm{~dB}$, 左側 $15 \mathrm{~dB}$ で あった．平衡機能検查は Romberg 現象陽性，足踏み検 査右方偏位, 右向きの水平回旋混合性の頭位眼振を認め 温度眼振検査では右 CP を認めた。一般血液扣よび生化 学検査等に異常なく，またCT および MRI 検査でも異 常所見は認められず突発性難聴と診断した．初診時より デキサメタゾン $8 \mathrm{mg}$ からのステロイド療法を開始. 受 診後 5 日目の平均聴力は $94 \mathrm{~dB}$ と悪化し以後回復傾向 はみられず，第14病日にデフィブラーゼ®の投与を開始 した.デフィブラーゼ®の初回投与量は $5 \mathrm{BU}$ (投与前の
血漿フィブリノゲン濃度が $200 \mathrm{mg} / \mathrm{dl}$ と正常值下限で あったこと，患者が合併症の説明に対し不安感を示した ことによる)で，投与開始翌日には平均聴力 $45 \mathrm{~dB}$ とな り著明な聴力改善が認められた。 4 日後の第18病日には 聴力は $35 \mathrm{~dB}$ とさらに改善して拈り, デフィブラーゼ® $10 \mathrm{BU}$ の追加投与を施行した。 しかしその後の聴力改 善は認められず $30 \mathrm{~dB}$ で注滦固定し，治療を終了した (図 3 ).

\section{考察}

バトロキソビン製剤(デフィブラーゼ®)は，蛇毒より 精製された分子量約 36,000 糖蛋白で，トロンビン類似 作用を持ちフィブリノゲンに直接作用しフィブリン様物 質を形成する。これはトロンビンにより形成されたフィ ブリンと異なり，凝固血栓の架橋形成ができず結合力が 脆弱で, 線溶系の働きにより速やかに血中から分解・消 失する。このため血管内凝固を発生させることなく血漿 フィブリノゲン濃度の減少が得られる。血漿フィブリノ ゲン濃度の減少は血液粘稠度を低下させ5)，それに伴う 血流速度の上昇が得られ6), また, 抗 2 次血栓効果が加 わり末梢循環を改善するとされている7).

一般的に血漿フィブリノゲン濃度が $60 \mathrm{mg} / \mathrm{dl}$ 以下に なると，諸種の凝血検査の凝固時間が延長し，出血傾向 も現れることがあるとされている8). またデフィブラー 


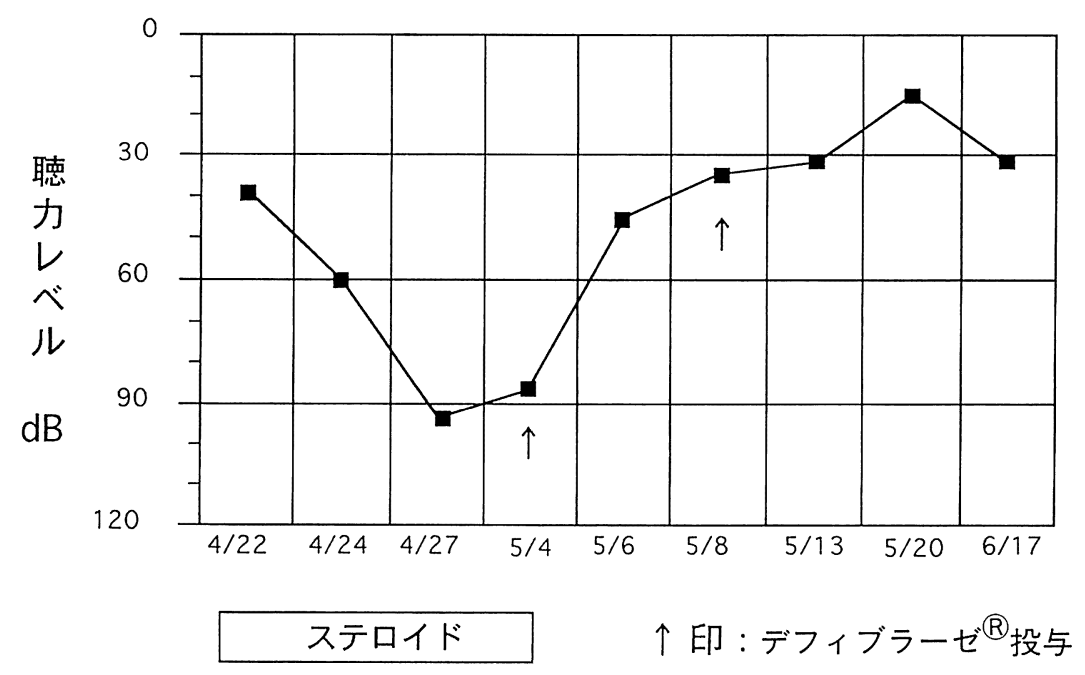

図 3 症例の経時的聴力変動

ゼ®は，血小板に対してはほとんど影響をおよぼさない とされているが，動物実験に括いて血漿フィブリノゲン 濃度が $50 \mathrm{mg} / \mathrm{d} 1$ 以下になると血小板凝集能が低下する といら報告9)やアスピリン併用時に毛細血管出血が 68.0 \%に増加したといら報告10)もあり注意が必要である.

一方, 慢性動脈閉塞症患者のフィブリノゲン濃度を 100 〜 $50 \mathrm{mg} / \mathrm{dl}$ に減少させたとき，血液粘稠度が $25 \sim 42 \%$ 低下を示したと報告11)されていることより，フィブリ ノゲン濃度を一定以上減少させることは, 末梢循環動態 を改善させるために重要と思われる．これらのことより 安全性, あるいはその治療効果を考慮すれば, デフィブ ラーゼ®投与に際しては血漿フィブリノゲン濃度を 50 $\sim 100 \mathrm{mg} / \mathrm{dl}$ 程度に維持するのが理想と思われる.

突発性難聴に対するデフィブラーゼ®投薬は, 内耳の 末梢循環不全の存在を仮定し，その改善を目的として使 用されるわけである.突発性難聴の病態は依然不明であ り，このような末梢循環障害の存在はあくまで推測でし かなく, デフィブラーゼ®の使用にあたっては, 安全性 に対する配慮がより重要である. 健常者におけるデフィ ブラーゼ®投与では 24 時間後にフィブリノゲン濃度は最 低值を示し，0.1 BU $/ \mathrm{kg}$ と $0.2 \mathrm{BU} / \mathrm{kg}$ 投与でとれぞれ 24 時間值で $50 \%$ と $70 \% ， 48$ 時間值で $30 \%$ と $43 \%$ の減少が 得られるとされる ${ }^{22}$. 今回, バトロキソビン製剤の再投 与にあたっては頻回に血液検査を施行し,フィブリノゲ ン濃度 $100 \mathrm{mg} / \mathrm{dl}$ 以上を確認後 $10 \mathrm{BU}$ (約 $0.2 \mathrm{BU} / \mathrm{kg}$ ) を再投与することを原則とした。しかし 8 症例に执いて
はデフィブラーゼ®投与後に血漿フィブリノゲン濃度が $50 \mathrm{mg} / \mathrm{d} 1$ 以下に低下した。急性効果を期待し初回量と して $20 \mathrm{BU}$ を投与した 4 症例中 3 例と， 2 回目以降の $10 \mathrm{BU}$ 投与後の 5 例である. 臨床症状に出血傾向はみ られなかったが反省すべき点であり，今後 $20 \mathrm{BU}$ の投 与は控えるとともに，2 回目以降の投与は $0.1 \mathrm{BU} / \mathrm{kg}$ を基準とし， $5 \mathrm{BU}$ 程度の投与が適当であろら。また複 数回の投与に際し, 連続 2 回のデフィブラーゼ®投与で 聴力改善がみられない症例は, それ以後のデフィブラー ゼ囚投与により聴力が改善した例は今回みられず，無意 味な投与を控える意味で中止すべきと思われる.

突発性難聴の病因として側頭骨病理所見からはウィル ス説が有力であるが13), 可逆性の病変を示寸例が多いこ と, 循環改善剤に反応し急速に難聴が改善する症例がみ られることなど, 既存のウィルス性難聴と異なる経過が みられることなどから循環障害説も支持されている。し かしいずれにしても突発性難聴の原因はいまだ明らかと はなっていない. 突発性難聴に対する治療の立場からは, ステロイド療法はその抗浮腫作用・抗アレルギー作用・ 抗炎症作用により有効性が確立されて扣り 14) 16), わが 国に括いてはステロイド剤を軸にビタミン剂や各種の循 環改善剂が併用される場合が多い，施設は限られるが高 圧酸素療法も聴力の改善に有意の有効性を認めている ${ }^{17)}$.

今回のわれわれの検討では, ステロイド療法にデフィ ブラーゼ®を併用し, 軽度回復以上 $76.5 \%$ の治療結果を 得た.今回はステロイド療法に抵抗した突発性難聴症例 
を中心にデフィブラーゼ®を使用したことを考慮すれば， その併用効果は比較的高いものであったと思われる。し かし聴力の改善を症例全体の平均聴力で検討した場合， 投与前聴力が約 $89 \mathrm{~dB}$ であるのに対し投与 1 力月後の 聴力は約 $66 \mathrm{~dB}$ で, ステロイド漸減中の症例もあり, 突発性難聴の自然回復等も考慮すると, デフィブラー ゼ®が極めて高い有効性を示したとはいいがたい。また デフィブラーゼ®使用に際し，日本耳鼻咽喉科学会専門 医通信18)で慎重に対応するよう注意がなされており， 本剤の使用には少なからず制限がある，従ってその適応 決定の条件あるいは比較的強い副作用の問題からも，突 発性難聴の第一選択薬剤とするには難しい点がある。し かし，ステロイド療法の効果が得られず治療に難橴する 突発性難聴のなかに，デフィブラーゼ®投与後より急速 に難聴の改善する症例がみられたことも事実である。こ のことは, デフィブラーゼ®はステロイドとは異なった 機序で治療効果を有すると推測され，ステロイドが無効 である症例にデフィブラーゼ®を使用してみる価值が充 分あることがわかる，その際，デフィブラーゼ®は二次 的な治療方法と考光，その副作用に精通し，より安全な 投与方法が選択されることが重要であろう。適切な投与 法のもとに使用することで，特殊な薬理作用を持つ本剂 の適応症例は広がることになり, 結果として突発性難聴 の治療成績を向上させることが期待される.

\section{まとめ}

1. ステロイド㶡の効果が不充分であった突発性難聴 症例を中心にバトロキソビン製剤(デフィブラーゼ®)を 併用し，その効果を検討した。

2. 17症例に対する聴力改善の評価は, 治瘉 1 例 ( 6 $\%)$, 著明回復 5 例 $(29 \%)$, 軽度回復 7 例 $(41 \%)$, 不変 4 例 $(24 \%)$ で, 軽度回復以上は 13 例, $76.5 \%$ であった。

3. デフィブラーゼ®投与により，17例中 8 例が血漿 フィブリノゲン濃度が $50 \mathrm{mg} / \mathrm{d} 1$ 以下に減少したが, 臨 床状問題となる副作用は認めなかった。

4. 安全性, 有効性を考慮すれば，血漿フィブリノゲ ン濃度を $50 \sim 100 \mathrm{mg} / \mathrm{dl}$ に保つことが重要と思われた。

5 . 安全性を重視し，適切な投与法のもとに使用する ことで, 本剤は突発性難聴の治療成績の向上が期待され る.
本論文の要旨は, 1994年 9 月, 第104回日耳鼻東京都地方部 会でロ演した。

\section{文献}

1) 久保 武, 奥村新一, 浅井英世, 他：突発性難聴に対する 脱線維素原療法について. 耳鼻 $31: 1231 \sim 1236,1985$.

2 ) 浅井英世, 久保 武, 白石孝之, 他 : 突発性難聴に対する 脱線維素原療法と既存療法との比較検討. 臨床医薬 1 : 1189 1199, 1985.

3 ) 松永 亭, 久保 武, 河本和友, 他 : 突発性難聴に対寸る 脱線維素原療法 (batroxobin) の治療効果 一betamethasone を対照とした二重盲検比較法による検討一. 医学のあゆみ $137: 499 \sim 508,1986$.

4 ）鈴木幹男, 北西 剛, 佐伯紀子, 他 : 突発性難聴に対する 脱線維素原療法の経験. 耳鼻臨床 $87: 711 \sim 717,1994$.

5 ) 安永幸二郎, 熊田肇, 松田香苗: 蛇毒 batroxobin (Defibrase ${ }^{\circledR}$ ) 飞よる治療患者の凝血学的検討.内科宝函 $26: 465 \sim 474,1979$.

6 ）枆谷文彦, 伯耆徳武, 友永 轟, 他 : 光ファイバ・レーザ システムによる動脈血流計測装置(下), 薬剤効果の検討.

新医療 $8: 11 \sim 13,1981$.

7 ）上野達雄, 田中 広, 竹内秀雄, 他 : 実験的血栓形成に対 する血墏フィブリノゲン濃度の影響. 日本血液学会雑誌 $44: 726 \sim 731,1981$.

8 ) 藤巻道男, 羽田雅夫 : フィブリノゲン. 内科 $61: 1219$ 1220, 1988

9 ) Egberg $\mathrm{N}$ and Nilsson SEG : Treatment of central retinal vein thrombosis with Defibrase induced defibrination. Defibrinierung mit thrombin-ähnlichen Schlangengiftenzymen (ed by Martin M). pp 231 232, Bern-SuttgartWien, 1975.

10) Olsson $P$ and Johnsson $H$ : Inteference of acetyl salicylic acid, heparin and fibrinogen degradation products in haemostasis of Reptilase-defibrinogenated dogs. Thrombos Res 1 : 135 146, 1972.

11) Völker $D:$ Rheologische Veränderungen unter der Therapie mit defibrase. Defibrinierung mit thrombinähnlichen Schlangengiftenzymen (ed by Martin M and Schoop W). pp 171 178. Huber, Bern-Stuttgart-Wien, 1975.

12）福武勝博, 藤巻道男, 長沢 洋, 他: 蛇毒酵素 Batroxobin (Defibrase)の健康人に拈ける安全性および臨床薬理 学的検討. 日本血液学会雑誌 $44: 1178 \sim 1194,1981$.

13) Schuknecht HF, Kimura RS, Naufal PM : The pathology of sudden deafness. Acta Otolaryngol $76: 75 \sim 97,1973$.

14）柳田則之, 三宅 弘：突発性難聴の治療. 耳鼻 $24: 28$ 42, 1978. 
15）設楽哲也, 小田 恂, 立木 孝, 他 : 突発性難聴に対する 薬剤効果の評価. 耳鼻 $24: 1006 \sim 1027,1978$.

16) Moskowitz D, Lee KJ and Smith HW : Steroid use in idiopathic sudden sensorineural hearing loss. Laryngoscope $94: 664 \sim 666,1984$.

17）柳田則之, 丹羽英人, 榊原文作, 他 : 突発性難聴に対する 高圧酸素療法. 耳喉 $45: 539 \sim 551,1973$.
18）岡本途也, 曽田豊二 : 突発性難聴に対するバトロキソビン 製剂(デフィブラーゼ®)の保険薬収載の経緯. 日本耳鼻咽 喉科学会専門医通信 $20: 11 \sim 12,1989$.

$$
\left(\begin{array}{l}
\text { 別刷請求先 : 弘重光一 } \\
\text { †173 東京都板橋区大谷口上町 } 30-1 \\
\text { 日本大学医学部耳鼻咽喉科学教室 }
\end{array}\right)
$$

